Article Type: Research Paper

\title{
The Ethical Perspective of Millennial Accountants in Responding to Opportunities and Challenges of Blockchain 4.0
}

\author{
Sendy Dwi Haryanto ${ }^{1 *}$ and Erina Sudaryati ${ }^{2}$
}

\begin{abstract}
:
Research aims: This study aims to provide a perspective on the professional ethics of a millennial accountant in applying blockchain technology to improve his professionalism, and discusses the issue of blockchain ethical challenges for an accountant's profession

Design/Methodology/Approach: A research approach is a qualitative approach with interviews with the millennial accountants, namely millennial corporate accountants, millennial research accountants, and millennial internal auditors. Research findings: The study results indicated that a millennial accountant in the 4.0 revolution era is required to adapt to technology. The blockchain technology extends the ethical approach to utilitarianism to a broader social level with decentralization in serving stakeholders' information needs. Blockchain changes the task of millennial accountants who previously produced information into information evaluators. Millennial accountants must change their mindset to absorb the essence of the accountant's code of ethics and harmonize ethical values. It is the basis for acting ethically to avoid the moral dilemma of technological adaptation.

Theoretical contribution/Originality: The contribution of this research for accountants is to build a moral-ethical perspective in adopting blockchain technology that prevents potential impacts on business and society and to describe the challenges that the accounting profession will face in adopting blockchain in the industrial revolution 4.0.

Practitioner/Policy implication: The implications of this study illustrate that the blockchain can change perspectives in real-time accounting to reduce practitioners' mistakes from the accounting profession by considering the ethical and moral aspects of a millennial accountant.

Research limitation/Implication: The limitation of this study is the first; it has not yet deepened the three challenges faced by millennial accountants in the revolutionary 4.0 era. Secondly, millennial educator accountants have not yet to be involved as interviewees.

Keywords: Ethical Dilemma; Millennial Accountants; Revolution 4.0; Utilitarianism
\end{abstract}

Haryanto, S. D., \& Sudaryati, E. (2020). The Ethical Perspective of Millennial Accountants in Responding to Opportunities and Challenges of Blockchain 4.0 . Journal of Accounting and Investment, 21(), 452-470.

\section{ARTICLE HISTORY}

Received:

21 Jun 2020

Reviewed:

28 Jun 2020

Revised:

$13 \mathrm{Jul}$

Accepted:

16 Jul 2020

\section{Introduction}

The development of blockchain technology began in the last decade accompanied by the growth of cryptocurrency and bitcoin in 2009, which affected the cycle or function of accounting and financial reporting (Fuller \& Markelevich, 2020; Sinha, 2020). Blockchain offers a new way to record, 
The Ethical Perspective of Millennial Accountants in Responding ...

process, and store transactions and financial information to change the accounting profession's perspective to reshape the integrated business ecosystem ( $\mathrm{Liu}, \mathrm{Wu}, \& \mathrm{Xu}$, 2019).

Other implications of the next blockchain technology are data processing, transmission, storage, and data security (Brandon, 2016; Gross, Hemker, Hoelscher, \& Reed, 2017). Supported by previous research, Blockchain has the potential to create new ecosystems in handling accounting information (Dai \& Vasarhelyi, 2017; Kokina, Mancha, \& Pachamanova, 2017).

Blockchain itself is a public ledger as a place for several groups of transactions that are recorded and stored in a data structure such as chains that adjusted to blocks based on transaction time (Simoyama, Grigg, Bueno, \& Oliveira, 2017). The development of blockchain technology is divided into two types, namely unlicensed blockchain and permitted blockchain (Zheng, Xie, Dai, Chen, \& Wang, 2018). Blockchain without permission illustrated with one of the information can be shared, updated, monitored, owned, and controlled by everyone both individuals and organizations in decentralized, while for the permitted blockchain, it refers to a blockchain that has some restrictions in membership and there are control procedures (Liu et al., 2019).

The blockchain has been developed and adopted by businesses today, which supports various business sectors, such as banking, trade, insurance, health services, transportation, and government ( ØInes, Ubacht, \& Janssen, 2017; Tan \& Low, 2019; Yermack, 2017). It will be expected to impact the accounting and audit profession in the future (Coyne \& McMickle, 2017; Dai \& Vasarhelyi, 2017; Kokina et al., 2017). Blockchain is in the spotlight used in various industries that show progress and are not only limited to cryptocurrencies but can affect the cycle or function of accounting and financial reporting (Sinha, 2020).

An accountant's essential characteristic in producing information is the high reliability of accounting information, where investors and auditors like reliable data or information (Fuller \& Markelevich, 2020). Current efforts explore how accounting information can be modified to integrate with blockchain technology (Vetter, 2018). Furthermore, the reliability of information integrated with the Blockchain is supported by (Sinha, 2020), which shows that the benefits of blockchain technology are strength, deletion, and consensus mechanism. These characteristics can ensure that there is no time lag between the occurrence of transactions and the accounting system's recording system that cannot be changed.

These technological advances have made it possible for the accounting profession to develop and build blockchain-based accounting practices to improve business information systems (Andersen, 2016; Brandon, 2016). The accountant profession will indirectly benefit significantly from blockchain technology due to several factors, starting from the level of data storage security, the process of sharing information relevant to stakeholders, and the verification process of accounting transactions (Dai \& 
Vasarhelyi, 2017). It is a consideration for the accounting profession to implement blockchain technology to change the latest business ecosystem.

The other side that needs to consider regarding the reliability of information for an accountant produced when implementing blockchain is the level of cyber information security. The negative side of the implementation of the blockchain is indeed quite high the impact that will be felt by accountants and companies (Demirkan, Demirkan, \& McKee, 2020). Blockchain can pose a threat to the business environment and the parties involved (Barzilay, 2017). The accountant profession can disrupt the digitalization of technology, namely adaptability, cost, and difficulty levels that are quite high (Murthy, 2016; Sinha, 2020). An unexpected negative impact will cause the failure of the company's goals. Aside from the accountant profession side, there is a negative impact on the government, namely increasing energy consumption, which is very high for calculating blockchain transactions (Hooper \& Holtbrügge, 2020).

The perception of four audit firms (big four) about the implementation of blockchain technology benefits the accounting profession. PricewaterhouseCoopers, for example, has a perception that Blockchain is a software to improve the next generation of business processes that change practices by integrating clients, competitors, and suppliers in activities in his profession (PricewaterhouseCoopers, 2016b). Likewise, Deloitte (2016) expressed his hope that the blockchain could increase collaboration between businesses and individuals, data transparency, and productivity for business sustainability (Dai, He, \& Yu, 2019). In Indonesia, the Indonesian Institute of Accountants through Prakasa 6.1 stated the macro trends and implications for the profession of applying information technology. Artificial intelligence, blockchain, cloud, big data, the Internet of things, and robotics have disrupted conventional economic order while presenting new business models (Ikatan Akuntan Indonesia, 2019).

Then, what about the ethics of an accountant? The ethical importance of implementing technology is not just the benefits gained in the business process and stakeholders. Underlined in Blockchain's implementation is a decentralized, democratic, and disintermediary system (Dierksmeier \& Seele, 2020). Governance based on blockchain implementation can influence business processes, both offline and online, which will indirectly experience debates relating to business ethics that oppose the status quo.

An ethical assessment of this technology from the perspective of "information ethics" introduced by Floridi (2013) defines that "information ethics" is an information philosophy that has an ethical impact on the implementation of information technology concerning human and community life. The renewal of blockchain technology from decentralization requires the approach of two parties: decision-makers in business and policymakers or regulators (Dierksmeier \& Seele, 2020). The phenomenon of blockchain technology adoption is still limited and needs to be considered for its development. Moral and ethical challenges need to be addressed to understand the potential consequences of blockchain technology (Tang, Xiong, Becerril-Arreola, \& Iyer, 2019a). The ethical importance of blockchain technology is its implementation, which will impact the business world and society. 
The accounting profession's ethics stated by Duska, Duska, and Kury (2018) is that the accounting profession's ethics is a behavior related to right or wrong, and good or bad concerning the principles of life the individual or disciplines to study ethical principles. Ethical behavior is going to be used to analyze and evaluate individual practice. The role of the millennial accountant profession to support the 4.0 revolution is required to improve the capabilities associated with the process of analyzing lots of data and making decisions based on data with complex problem-solving, leadership skills, and interpersonal skills (Setiawan, Lusanjaya, \& Kurnia, 2019). Moreover, Sumarna (2020) supports that soft skills in critical and analytical thinking are needed by the accountant profession, which is used as a benchmark to prepare professional accountants who can compete in the 4.0 industrial revolution era.

The utilitarianism perspective of an accountant who implements blockchain technology raises the positive side. Utilitarianism does not pay attention to the privacy side but is based more on how the utility in the aggregate use of blockchain technology (Dierksmeier \& Seele, 2020). This perspective does emphasize optimizing utility outcomes to provide satisfaction or happiness (Davison, 2000; Stahl, 2012). Blockchain technology has expanded the realm of ethical utilitarianism in cloud computing to serve the needs of all parties (Miller, 2010). Decentralization through blockchain technology provides good governance through records and ownership that does not affect transparency (Tang, Xiong, Becerril-Arreola, \& Iyer, 2019b; Yermack, 2017).

Research related to blockchain technology ethics is still lacking (Fischer, 2018; Tang et al., 2019a). It is in contrast to research related to the implementation of the blockchain in the field of accounting and its profession, where the audit process has the most potential application of the blockchain (Dai et al., 2019), the taxation system (Tang et al., 2019a), financial/banking services (Fanning \& Centers, 2016), and corporate social responsibility (Dierksmeier \& Seele, 2020). Previous research (Tang et al., 2019a) stated that blockchain ethics and its application are essential for technology adoption to prevent potential negative consequences and impact business and society. Sheldon (2018) argued that networks produced by blockchain technology could record violations and allow the accounting profession to exchange information without the risk of committing violations. Blockchain can help combat aggregation and problems with realtime updates, and cannot change information and confirmations to prevent fraud.

Based on a literature review from several previous studies, the researcher aims this study first to provide an ethical perspective on an accountant's profession in applying blockchain technology to improve professionalism. Secondly, it is to discuss the problem of ethical blockchain challenges for an accountant's profession. The urgency of this research is that the researcher wants to revoke the ethics of the accounting profession that faces the challenges of implementing the Blockchain in the industrial revolution 4.0. This study illustrates how Blockchain can change the perspective in real-time accounting to reduce practitioners' mistakes from the accounting profession. This study also considers the ethical and moral aspects of the blockchain-based business model. The contribution of this research for accountants is to build a moral-ethical perspective in adopting blockchain technology that prevents potential impacts on business and society 
and to describe the challenges that the accounting profession will face in adopting Blockchain in the industrial revolution 4.0.

\section{Literature Review}

\section{Blockchain Technology}

The technology was first introduced by Nakamoto (2008), which to use for digital currency exchange infrastructure that is centrally controlled by the government (e.g., bitcoin) (Fuller \& Markelevich, 2020). Blockchain technology offers a new way to record, process, and store transactions and financial information with the accounting profession's potential perspective to reshape the integrated business ecosystem (Liu et al., 2019). Blockchain itself is a public ledger used as a place for several groups of transactions to be recorded and stored in a data structure, like chains adopted to blocks and chains based on transaction time (Simoyama et al., 2017).

\section{Blockchain and accounting}

Blockchain is in the spotlight used in various industries that show the progress that is not only limited to cryptocurrencies and can affect the cycle or function of accounting and financial reporting (Sinha, 2020). Blockchain is one of the latest technologies that can transform invoices, payment processing, contractual agreements, and records that have implications for accountants' performance, financial professionals, and regulators (Baron, 2017; Dai \& Vasarhelyi, 2017). Besides, Kokina et al. (2017) stated that blockchain technology is used to develop accounting system triple-entry, which is possible to implement it as an intermediary to automate the storage and verification of transactions in forensic accounting. Transaction verification using blockchain technology can improve transaction data security or be reliable based on generally accepted accounting standards (Coyne \& McMickle, 2017).

\section{Blockchain and Professional Ethics}

The reliability of accounting information data is one of the benefits resulting from the implementation of the blockchain, where the financial statement audit process only requires less time to verify the accuracy of the data (Fuller \& Markelevich, 2020). Moral and ethical challenges need to be addressed for understanding the potential consequences that may be caused by the implementation of blockchain technology (Tang et al., 2019a). Another statement from Duska et al. (2018) argued that a person must be ethical because it can make a person aware of the principles used in determining what to do in situations involving ethical issues. Research from Dierksmeier and Seele (2020) supports that one's moral judgment viewed from the ethical evaluation side will change depending on someone who analyzes it through the view of utilitarianism, contractarianism, deontology, virtue ethics, and respectively. 
The Ethical Perspective of Millennial Accountants in Responding ...

\section{Blockchain and Millennial Accountant Ethics}

The ethics of the accounting profession were defined by Duska et al. (2018) as a behavior that is right or wrong and good and bad by the principles of the life of the individual or disciplines to study ethical principles. Ethical behavior is used to analyze and evaluate individual practice. Meanwhile, Stuart, Stuart, and Pedersen (2014) stated that accountant ethics is an ethical awareness, reflection, and assessment of ethical issues in accountants' discipline, enhancing the ability of accountants in action based on assessment. Accountant ethics education must be oriented towards ethical decisionmaking in practice.

The role of the millennial accountant profession to support the 4.0 revolution is necessary to improve the ability with lots of data and make data-based decisions with complex problem-solving methods, leadership skills, and interpersonal skills (Setiawan et al., 2019). Furthermore, Sumarna (2020) supports that soft skills in critical and analytical thinking are needed by the accountant profession, which is used as a benchmark between KJA to prepare professional accountants who can compete in the industrial revolution era 4.0.

\section{Research Method}

This research approach is qualitative. This study used critical methodological elements from the research of Kihn and Ihantola (2015) and Suddaby (2006), who specialized in accounting and management research, including research strategies, identification, selection of interview subjects, data analysis methods, data sources, and use of technical languages (evaluation criteria). This study employed primary data obtained based on the interview process.

In-depth unstructured interviews have used extensively to explore the dynamics of change in accounting (Alsharari \& Al-Shboul, 2019; Lukka, 2007). The interviewees of this study were two young accountants. The researcher determined the first because of a corporate accountant in export and import companies. The second interviewee was a young research assistant who studied financial accounting research. The third one was an internal auditor in a distribution company. The interview results were recorded, which were then analyzed by the researcher.

Data analysis introduced by Saunders (2011) shows the main processes that can be applied in data analysis to strengthen the interpretation of meaning. It includes summarizing meanings, categorizing (grouping) meanings, and structuring meaning using descriptions (Alsharari \& Al-Shboul, 2019). Modifications of this analysis were expected to be able to describe the researcher in-depth and convince the explanation of accounting changes.

The researcher modified interview questions from Schmitz and Leoni (2019) and Tang et al. (2019a). The researcher adjusted the need to answer this research questions related 
to the understanding and challenges that must be faced by the accountant profession in the implementation of the Blockchain and the ethical perspective of the accounting profession that adopted to the Indonesian accountant's code of ethics in understanding the adoption of Blockchain in generation 4.0.

\section{Result and Discussion}

\section{Utilitarianism Theory as the urgency of millennial accounting}

The traditional ethical theory supports the discussion of ethics in information systems. This research employed a utilitarianism approach, which emphasizes maximizing the output of the use of (utility) (Davison, 2000; Stahl, 2012). According to McPhail and Walters (2010), the theory of utilitarianism is a theory of goodness in which the consequences of one's actions. Therefore, this theory explains that action is right, which generates benefit by involving not only one person but a group of people. Criteria related to this theory are pro and contra, determining the happiness of the community or the people.

It is contrary to deontology theory, which refers to very high tasks and intentions but does not pay attention to the consequences caused (Mingers \& Walsham, 2010; Stahl, 2012). The utilitarian approach shows that ethical action in doing the best and least harmful compared to other ethical approaches (Lapointe \& Fishbane, 2019). The utilitarian approach will go hand in hand with a shift from the trust to the transparency of information (Brännmark, 2009; Dierksmeier \& Seele, 2020). Blockchain extends the ethics of utilitarianism to a broader social level through cloud computing to serve all parties' information needs (Miller, 2010; Tang et al., 2019b). Transparency in blockchain implementation is indeed essential for a millennial accountant. One millennial accountant thought that:

\footnotetext{
"Accounting information for a publicly owned company certainly belongs to the public. Information is neutral. The problem is someone's perception of the information (in this case, the accountant/auditor). It is ethical if the information does not carry personally from the accountant. Blockchain implementation will still have high ethical value if it only accesses accounting information, not information related to its accountants".
}

As it is known, Dierksmeier and Seele (2020) states that the utilitarianism approach does not pay much attention to privacy but instead emphasizes the good impact resulting from utilities. The benefits of transparent information covering a more comprehensive range will have a good impact. The Indonesian Institute of Accountants through Prakasa 6.1, concerning the macro trend of the professional environment, demonstrates transparency and accountability in the public sector. There needs to be increased the oversight of public finance and the demand for information that has characteristics including transparency, overall, and accuracy for the decision-making process (Ikatan Akuntan Indonesia, 2019). 
The Ethical Perspective of Millennial Accountants in Responding ...

Blockchain enhances ethical benefits that balance the information needs and fairness of a wider distribution of information (Madsen, 2009). The appropriateness of the utilitarianism approach and implementation of the blockchain is supported to facilitate a millennial accountant's performance, where they argued that:

"Utilitarianism is a view that prioritizes the usefulness of all parties. The existence of blockchain implementation will minimize (information asymmetry), so it is almost sure that management moves according to investors' wishes and can reduce monitoring costs".

Miller (2010) and Tang et al. (2019a) affirmed that the blockchain's implementation could expand the ethics of utilitarianism to a broader social level through cloud computing to serve the information needs of all parties. A millennial accountant must balance the utilitarianism approach to maximize the advantages of the blockchain. Blockchain implementation can increase the rigidity and correctness of accounting information (the results of accountants' performance before the existence of the blockchain) so that the level of correctness of corporate accounting information is not in doubt.

\section{Opportunities and Challenges for Millennial Accountants in the implementation of blockchain}

Technology blockchain was introduced by Nakamoto (2008), used for digital currency exchange infrastructure that is centrally controlled by the government (e.g., bitcoin) (Fuller \& Markelevich, 2020). Blockchain technology offers a new way to record, process, and store transactions and financial information that can change the accountant's perspective to reshape an integrated business ecosystem (Liu et al., 2019).

Blockchain itself is a public ledger place of several groups of transactions that are recorded and stored in a data structure, like chains adopted to blocks and chains based on transaction time (Simoyama et al., 2017). Blockchain has developed and adopted by businesses today, which has supported various businesses, such as banking, trade, insurance, health services, transportation, and government ( $\varnothing$ Ines et al., 2017; Tan \& Low, 2019; Yermack, 2017); it will be expected to have an impact on the accounting and auditing profession (Coyne \& McMickle, 2017; Dai \& Vasarhelyi, 2017; Kokina et al., 2017).

It is for consideration for the accounting profession to implement blockchain technology to change the latest business ecosystem. These technological advances have made it possible for the accounting profession to develop and build blockchain-based accounting practices to improve business information systems (Andersen, 2016; Brandon, 2016). The same thing was stated by millennial accountants that:

"Blockchain cuts the workload of accountants and auditors, where the accounting cycle becomes instant, and even the auditor will be able to take charge of the company's dayto-day operations, not in annual units," said the researchers of accounting. 
The Ethical Perspective of Millennial Accountants in Responding ...

\begin{abstract}
"So that the opportunities for rapid technological development are currently making it easier for accountants and auditors to make decisions in the company. Blockchain offers various facilities, such as reducing maintenance costs, reconciliation processes, and time efficiency." said the corporate accountant.

"Accountants must capture the opportunities of this technology, where the blockchain can provide more detailed data on the company's transaction history so that the company's accounting records are more comprehensive and integrated," said the auditor.
\end{abstract}

Blockchain's main feature is the concept of decentralization because every record node (user in the computer) is stored, that is different and not in one location, and is easily accessed by anyone who has the authority but cannot be changed (Bonsón \& Bednárová, 2019). Thus, it will produce a level of efficiency, transparency, and secure transaction methods, storage of transaction records, and cannot be modified (Buterin, 2014). The process of producing efficiency, transparency, and information security is a challenge for millennial accountants who can collaborate with blockchain technology. The form of challenges currently faced by millennial accountants was:

"... need a strong understanding of the information system and the accounting cycle itself because it requires adaptability and a high level of difficulty to integrate the two knowledge clusters." said the corporate accountant.

"... reflected from the level of use of accounting software is low both at the lecture and company level. It makes the accountant does not make the blockchain a priority that must be prepared." said researchers of accounting.

" ... clear and standardized regulations, then the Indonesian Institute of Accountants need to work with governments and IT companies (e.g., SAP, Microsoft) to hold seminars and training on blockchain and their use in accounting and audit." said the auditor.

Several challenges indeed influence the adoption of the blockchain by accountants. The above statement is supported by Fuller and Markelevich (2020), which shows the challenges faced by accountants. Firstly, data security and privacy factors; secondly, issues regarding the process of adoption and integration of technology; and thirdly, implications of the blockchain on the accounting and audit functions. Moreover, Sinha (2020) states that the first is the cost and level of difficulty of implementing the blockchain, which can involve many parties; the second is the structure of information security; and the third guarantees the control system adequate security. Furthermore, challenges related to the professional ethics of accountants exist. Moral and ethical challenges need to be addressed for understanding the potential consequences that may be caused by the implementation of blockchain technology (Tang et al., 2019b). The ethical importance of blockchain technology is the implementation that will impact the business world and society. Regarding millennial accountants' opinions about aligning the accountant's code of ethics to ensure the success of the concept of decentralization from the implementation of the blockchain, they stated:

"The main code of ethics needed is the judgment of the accountant itself against accounting information. Blockchain does not conclude from that information, so the role 
The Ethical Perspective of Millennial Accountants in Responding ...

of the code of ethics is to uphold the principle of truth in concluding information from the blockchain."

Bonsón and Bednárová (2019) stated that challenges for the blockchain implementation are scalability, flexibility, architecture, and cybersecurity. The challenges that millennial accountants might face are related to the loss of some of the functions of the accountant's task replaced by the Blockchain. Millennial accountants stated that:

\footnotetext{
"Blockchain as one of the industrial revolution 4.0 technologies that will change the professional world. The accountant profession is a profession that is prone to be replaced, but that is if the accountant still has an old mindset. Accountants must now move from preparing accounting information to summarizing accounting information".
}

By IAI through Prakasa 6.0, the use of smart technology has revolutionized the traditional way of working with accountants. It creates many opportunities and challenges for the profession and its members, including encouraging outsourcing activities far beyond the jurisdictional boundaries (Ikatan Akuntan Indonesia, 2019). To deal with the 4.0 revolution, a millennial accountant will experience a change in the role that previously prepared accounting information to conclude information. A millennial accountant needs to increase technological knowledge, one of which is the blockchain but must pay attention to the cybersecurity, such as detection, response, and resilience (Akhter \& Sultana, 2018; Sumarna, 2020). Millennial accountants must improve the ability to work with data and make decisions based on data, have the creativity, and adjust to the subsidies that occur (Setiawan et al., 2019). The same statement was also stated by millennial accountants that:

"Surely, they must adapt to technology. History requires almost all great scientists from various disciplines to begin with social rejection".

The statement states that the challenges of a millennial accountant come not only from the technical and ethical aspects of the blockchain implementation but also from the social order. The social order side that is one of the challenges of an accountant is social rejection. Rejection faced is the impact of accountants in the blockchain adaptation process, namely the denial of the environment of colleagues in a profession that is not easy to adapt to technology. Therefore, millennial accountants face two choices: first, a millennial accountant who is easy to adjust to technological developments but will be criticized by the professional environment. Second, a millennial accountant who does not adapt to technological progress but has social and professional recognition.

Both of these choices are a dilemma of a millennial accountant today with the demands of his profession to collaborate with technology or prefer social recognition. However, again, the ethics of the accounting profession is a behavior related to right or wrong. Good or bad is used as a principle held by individuals or scientific disciplines to study ethical principles (Duska et al., 2018). It is undeniable that technology adaptation does have complex challenges in terms of technical, moral, and social aspects. It should be noted that the current business environment needs to integrate technology in 
The Ethical Perspective of Millennial Accountants in Responding ...

managerial processes to be competitive and produce value for the company (Marrone \& Hazelton, 2019; Weill \& Woerner, 2015).

\section{Millennial Accountant Ethics and Indonesian Accountant Code of Ethics}

Moral and ethical challenges need to be addressed for understanding the potential consequences that may be caused by the implementation of blockchain technology (Tang et al., 2019b). Indonesia itself, through the IAl, states that the basic principles of public accountant ethics are:

1. Integrity, where an accountant must be substantial, honest funds are provided in all professional and business relationships.

2. Objective, where an accountant must not allow subjectivity, conflict of interest, or influence from other parties that can influence professional or business considerations.

3. Professional competence and prudence, where an accountant maintains knowledge and professional expertise and acts professionally by technical and professional standards.

4. Confidentiality, where an accountant maintains the confidentiality of information generated from professional relationships and relationships with third parties without the client's consent or employer, except for legal obligations or professional rights to disclose, and does not misuse information for profit.

5. Professional behavior, where an accountant complies with the appropriate legislation and knows any behavior that reduces confidence in the profession.

The accounting profession's ethics is a matter of right and wrong behavior and good and bad by the principles of the life of the individual or disciplines to study ethical principles (Duska et al., 2018). Supported by Dierksmeier and Seele (2020), a person's moral judgment viewed from the side of ethical evaluation, which will change depending on someone who analyzes through the view of utilitarianism, contractarianism, deontology, and virtue ethics, respectively. Millennial accountants stated that:

"The most necessary ethical attitude is an adaptive attitude. This attitude will underlie all other ethical attitudes regulated in the accountant's code of ethics. The code of ethics compiled long before the phenomenon of technology emerged as it is now "

Prakasa $6.1 \mathrm{IAl}$ states that information technology, such as artificial intelligence, blockchain, cloud, big data, Internet of things, robotic, has disrupted conventional economic order while presenting a new business model (Ikatan Akuntan Indonesia, 2019). Thus, a millennial accountant must increase technological knowledge, one of which is the blockchain, but must pay attention to cybersecurity aspects, such as detection, response, and resilience (Akhter \& Sultana, 2018; Sumarna, 2020).

Is a blockchain application considered to be able to increase cost and time efficiency and reduce the risk of human error? The implications of the blockchain on the accountant and auditor profession will traditionally remain relevant in the future, although the fulfillment of tasks will change; it must be balanced with the skills needed, and it hoped 
The Ethical Perspective of Millennial Accountants in Responding ...

that the profession challenged to take advantage of this new opportunity (Schmitz \& Leoni, 2019). Millennial accountants stated that:

"The accountant profession is a profession that is prone to be replaced, but that is if the accountant still has an old mindset. Accountants must now move from preparing accounting information to concluding accounting information".

A millennial accountant in the era of revolution 4.0 is demanded to be able to adapt to technology. The accountant profession will indirectly benefit significantly from blockchain technology, which is related to the level of data storage security, the process of sharing information relevant to stakeholders, and the verification process of accounting transactions (Dai \& Vasarhelyi, 2017).

Apart from the accountant's code of ethics that has been issued by the Indonesian Institute of Accountants, millennial accountants must uphold integrity, objectivity, competence and prudence, confidentiality, and professional behavior. However, with the current technological developments, millennial accountants are expected to adopt changes in the code of ethics in an applicative manner without changing the essence of the code of ethics issued by the Indonesian Institute of Accountants. Millennial accountants should not only be limited to knowing and understanding the accountant's code of ethics, but the rest must absorb from the code of ethics itself so that it becomes a principle in carrying out his profession that is easily adaptable to technology. IAI also states that to demonstrate integrity and ethics in the professional practice of Indonesian accountants who are maintained and enforced consistently and sustainably, IAI runs a program related to updating the code of ethics and professional standards of accountant services, following the latest developments in standards issued by IFAC (Ikatan Akuntan Indonesia, 2019). By changing the task of millennial accountants, who previously produced information to conclude information, the accountant's code of ethics is demanded to maintain credibility in the practice of concluding the information generated. Therefore, millennial accountants are supposed to maintain an ethical code mostly, but they must adapt to technological developments in practice.

\section{Dilemma Millennial Accountant Ethics}

Advances in revolution 4.0 technology enable the accountant profession to develop and expand blockchain-based accounting practices to improve business information systems (Andersen, 2016; Brandon, 2016). Moral and ethical challenges need to be addressed for understanding the potential consequences that may be caused by the implementation of blockchain technology (Tang et al., 2019b).

The role of the millennial accountant profession to support the 4.0 revolution is necessary to improve the ability with lots of data and make decisions based on data with complex problem-solving methods, leadership skills, and interpersonal skills (Setiawan et al., 2019). The ethics of the accounting profession, as stated by Duska et al. (2018), is a right or wrong behavior and good and bad by the principles of the life of the individual or disciplines to study ethical principles. 
Millennial accountants face two choices, first, a millennial accountant who is easy to adapt to technological developments but will be criticized by the professional environment, or second, a millennial accountant who does not adapt to technological developments but has a social and professional recognition of himself. Both of these choices are a dilemma of a millennial accountant today with the demands of his profession to collaborate with technology or prefer social self-recognition. They argued that:

"not a dilemma, this is because millennial accountants should not only know and understand the accountant's code of ethics but also permeate the code of ethics itself. It will make the integration of accountants with blockchain technology stronger based on the accountant's code of ethics".

The code of ethics is made to upheld as an accountant's principle in carrying out his profession. An adaptive attitude is needed to adjust to the development of revolution 4.0 technology. The mindset of millennial accountants today needs to consider the applicability of the role of the code of ethics while still paying attention to the ethical values of an accountant relating to ethical behavior.

It is no longer the time for millennial accountants to experience ethical dilemmas related to right and wrong and good and bad, but they must have the advantage (benchmark) to be competitive in the 4.0 revolution. Millennial accountants must have soft skills in critical and analytical thinking to prepare professional accountants who can be competitive in the 4.0 revolution (Sumarna, 2020). Millennial accountants must first prepare to change the mindset related to the responsibility of an accountant toward his new task to deduce information generated from integration with blockchain technology. Secondly, millennial accountants must be brave to learn new things related to information systems to support competitiveness millennial accountants in revolution 4.0.

\section{The Urgency of Millennial Accountant Ethics in the 4.0 Revolution}

The accountant profession's role is still very crucial in creating the effectiveness and balance of changes that are happening. Ethics, integrity, and values held by accountants are believed to direct this disruption substantially. Growth in Indonesia prompted IAI to develop a macro trend for a competent accountant, namely technology, globalization, regulation, aspects of human resources, and the professional environment.

Indonesia's readiness is still lacking, so there needs to be an increase in the use of technology. It requires the outsourcing of traditional resources to integrate technology to improve task efficiency. It is reflected by the low level of accounting software used at the professional education level of accountants and companies. (PricewaterhouseCoopers, 2016a) revealed the results of research in 2016 on the level of digitalization of the company in the industrial revolution 4.0 in countries that AsiaPacific would experience a significant increase with several $31 \%$ to $67 \%$ in 2020 , which previously only ranged in numbers $36 \%$ in the previous year. 
The Ethical Perspective of Millennial Accountants in Responding ...

This increase demands accountants' role to develop and build blockchain-based accounting practices to improve business information systems (Andersen, 2016; Brandon, 2016). IAl requires accountants to improve public financial oversight and the demand for information with characteristics, including transparency, overall, and accuracy for the decision-making process (Ikatan Akuntan Indonesia, 2019). Millennial accountants must know that accounting information's reliability can be beneficial for investors and auditors in the decision-making process (Fuller \& Markelevich, 2020). The use of technology does have a positive impact related to the efficiency of accountants' duties. The same thing is shown by Coyne and McMickle (2017), which states that verification of transactions generated by Blockchain can improve transaction data security and rely on generally accepted accounting standards.

Millennial accountants will face ethical challenges to understand the consequences of the implementation of blockchain technology (Tang et al., 2019a, 2019b). The use of blockchain technology can indeed expand utilitarianism's ethics to a broader social level, and it is due to the concept of decentralization through cloud computing to serve the information needs of all parties (Miller, 2010; Tang et al., 2019a).

Revolution 4.0 that will be faced by a millennial accountant demands to change the duties and functions of the profession that the accountant used to prepare accounting information turned into limited information conclusions. Although the task and function of producing information have transferred to the Blockchain, cybersecurity aspects must still be considered by accountants for detection, response, and resilience (Akhter \& Sultana, 2018; Sumarna, 2020). Working with data is an additional skill that must be possessed by millennial accountants 4.0 to improve the ability for the decision-making process, high creativity, and adapt to the development of revolution 4.0 (Setiawan et al., 2019). The urgency that millennial accountants need to do is:

\footnotetext{
"First, change the mindset regarding accountant responsibility; now is the time to summarize accounting information, not make it. It can also be encouraged by the existence of an accountant's code of ethics in sync with the accountant's work changes. Second, dare to learn new things, namely information systems, and information security. It is because, of course, to maximize the use of the blockchain, we must surely understand the technology correctly."
}

The mindset to overcome the ethical dilemma of a millennial accountant that will be faced is to strengthen the responsibility within the accountant to meet the information needs. Millennial accountants must adapt to technological developments even though the professional environment will criticize the consequences. The choice of right or wrong, good or bad, comes back to a millennial accountant. Perceiving the ethical code is indeed not easy. It is not only limited to understanding it, but there is a need for commitment in millennial accountants by adapting to technology. Following IAI's code of ethics, it shows that an accountant must be able to uphold their integrity by being firm, honest, and fair in all professional and business relationships. Thus, integrity can change millennial accountants' mindset to be more logical and responsible, and their essence can be understood to overcome the ethical dilemma of adopting blockchain technology. 


\section{Conclusion}

Blockchain technology offers a new way of record, process, and store transactions and financial information, challenges, and opportunities for the accounting profession to reshape the business ecosystem integrated with technology. This study provides an ethical perspective on an accountant's profession in applying blockchain technology to improve his professionalism and discusses the issue of blockchain ethical challenges for an accountant's profession.

Blockchain technology to align with ethical benefits is to balance broader information needs and information transparency. The use of blockchain technology extends the ethical approach to utilitarianism to a broader social level with the concept of decentralization to serve the information needs of all parties. A millennial accountant in the 4.0 revolution era is demanded to be able to adapt to technology. Revolution 4.0 demands to change the duties and functions of the profession that used to be the accountant preparing accounting information to be limited to concluding information. Although the task and function of producing information have transferred to the Blockchain, cybersecurity aspects must still be considered by accountants for detection, response, and resilience.

The code of ethics is made to upheld as an accountant's principle in carrying out his profession. An adaptive attitude is needed to adjust to the development of revolution 4.0 technology. The mindset of millennial accountants today needs to consider the applicability of the role of the code of ethics while still paying attention to the ethical values of an accountant relating to ethical behavior.

Implications for millennial accountants are to build a moral-ethical perspective in adopting blockchain technology that prevents potential impacts on business and society and can illustrate the challenges that the accounting profession will face in adopting Blockchain in the industrial revolution 4.0. Millennial accountants will face challenges from social, ethical, and technical aspects to adapt in the revolutionary era 4.0. Future studies are expected to deepen the three challenges faced by millennial accountants in the revolutionary 4.0 era, then adding interviewees from educator millennial accountants.

\section{References}

Akhter, A., \& Sultana, R. (2018). Sustainability of Accounting Profession at the Age of Fourth Industrial Revolution. International Journal of Accounting and Financial Reporting, 8(4), 139. https://doi.org/10.5296/ijafr.v8i4.13689

Alsharari, N. M., \& Al-Shboul, M. (2019). Evaluating qualitative research in management accounting using the criteria of "convincingness". Pacific Accounting Review. 31(1), 4362. https://doi.org/10.1108/PAR-03-2016-0031

Andersen, N. (2016). Blockchain technology: A game-changer in accounting [Press release]. Retrieved from 
https://www2.deloitte.com/content/dam/Deloitte/de/Documents/Innovation/Bloc kchain A\%20game-changer $\% 20$ in $\% 20$ accounting.pdf

Baron, J. (2017). Blockchain, accounting and audit: what accountants need to know. Accounting Today. Retrieved from https://www.accountingtoday.com/opinion/blockchain-accounting-and-audit-whataccountants-need-to-know\#

Barzilay, O. (2017). 3 ways blockchain is revolutionizing cybersecurity. Retrieved from https://www.forbes.com/sites/omribarzilay/2017/08/21/3-ways-blockchain-isrevolutionizing-cybersecurity/\#77dc34b12334

Bonsón, E., \& Bednárová, M. (2019). Blockchain and its implications for accounting and auditing. Meditari Accountancy Research. 27(5), 725-740. https://doi.org/10.1108/MEDAR-11-2018-0406

Brandon, D. (2016). The blockchain: The future of business information systems. International Journal of the Academic Business World, 10(2), 33-40. Retrieved from https://blockchainlab.com/pdf/Ethereum white papera next generation smart contract and decentralized application platform-vitalikbuterin.pdf.

Brännmark, J. (2009). Ethical theories and the transparency condition. Ethical theory and moral practice, 12(5), 449. https://doi.org/10.1007/s10677-009-9160-z

Buterin, V. (2014). A next-generation smart contract and decentralized application platform. Ethereum White Paper, 3(37), 1-15. Retrieved from https://cryptorating.eu/whitepapers/Ethereum/Ethereum_white_paper.pdf

Coyne, J. G., \& McMickle, P. L. (2017). Can blockchains serve an accounting purpose? Journal of Emerging Technologies in Accounting, 14(2), 101-111. https://doi.org/10.2308/jeta-51910

Dai, J., He, N., \& Yu, H. (2019). Utilizing Blockchain and Smart Contracts to Enable Audit 4.0: From the Perspective of Accountability Audit of Air Pollution Control In China. Journal of Emerging Technologies in Accounting. 16(2): 23-41. https://doi.org/10.2308/jeta$\underline{52482}$

Dai, J., \& Vasarhelyi, M. A. (2017). Toward blockchain-based accounting and assurance. Journal of Information Systems, 31(3), 5-21. https://doi.org/10.2308/isys-51804

Davison, R. M. (2000). Professional ethics in information systems: A personal perspective. Communications of the Association for Information Systems, 3(1), 8-25. https://doi.org/10.17705/1CAIS.00308

Deloitte. (2016). Blockchain Technology: A Game changer in accounting? Retrieved from https://www2.deloitte.com/content/dam/Deloitte/de/Documents/Innovation/Bloc kchain A $\% 20$ game-changer $\% 20$ in $\% 20$ accounting.pdf.

Demirkan, S., Demirkan, I., \& McKee, A. (2020). Blockchain technology in the future of business cyber security and accounting. Journal of Management Analytics, 7(2), 1-20. https://doi.org/10.1080/23270012.2020.1731721

Dierksmeier, C., \& Seele, P. (2020). Blockchain and business ethics. Business Ethics: A European Review, 29(2), 348-359. https://doi.org/10.1111/beer.12259

Duska, R. F., Duska, B. S., \& Kury, K. W. (2018). Accounting ethics: John Wiley \& Sons.

Fanning, K., \& Centers, D. P. (2016). Blockchain and its coming impact on financial services. Journal of Corporate Accounting \& Finance, 27(5), 53-57. https://doi.org/10.1002/jcaf.22179

Fischer, D. (2018). Ethical and professional implications of blockchain accounting ledgers. Available at: https://doi.org/10.2139/ssrn.3331009

Floridi, L. (2013). Distributed morality in an information society. Science and engineering ethics, 19(3), 727-743. https://doi.org/10.1007/s11948-012-9413-4 
Fuller, S. H., \& Markelevich, A. (2020). Should accountants care about blockchain? Journal of Corporate Accounting \& Finance, 31(2), 34-46. https://doi.org/10.2139/sstn.3447534

Gross, A., Hemker, J., Hoelscher, J., \& Reed, B. (2017). The role of secondary sources on the taxation of digital currency (Bitcoin) before IRS guidance was issued. Journal of Accounting Education, 39(1), 48-54. https://doi.org/10.1016/j.jaccedu.2017.02.001

Hooper, A., \& Holtbrügge, D. (2020). Blockchain technology in international business: changing the agenda for global governance. Review of International Business and Strategy. 30(2), 183-200. https://doi.org/10.1108/RIBS-06-2019-0078

Ikatan Akuntan Indonesia, I. (2019). Prakarsa 6.1 Menguasai Perubahan, Menyiapkan Masa Depan! [Press release]. Retrieved from http://www.iaiglobal.or.id/v03/materipublikasi/materi-131

Kihn, L.-A., \& Ihantola, E.-M. (2015). Approaches to validation and evaluation in qualitative studies of management accounting. Qualitative Research in Accounting \& Management. 12(3), 230-255. https://doi.org/10.1108/qram-03-2013-0012

Kokina, J., Mancha, R., \& Pachamanova, D. (2017). Blockchain: Emergent industry adoption and implications for accounting. Journal of Emerging Technologies in Accounting, 14(2), 91100. https://doi.org/10.2308/jeta-51911

Lapointe, C., \& Fishbane, L. (2019). The blockchain ethical design framework. Innovations: Technology, Governance, Globalization, 12(3-4), 50-71. https://doi.org/10.1162/inov a 00275

Liu, M., Wu, K., \& Xu, J. J. (2019). How Will Blockchain Technology Impact Auditing and Accounting: Permissionless versus Permissioned Blockchain. Current Issues in Auditing, 13(2), 19-29. https://doi.org/10.2308/ciia-52540

Lukka, K. (2007). Management accounting change and stability: loosely coupled rules and routines in action. Management Accounting Research, 18(1), 76-101. https://doi.org/10.1016/i.mar.2006.06.006

Madsen, P. (2009). Dynamic transparency, prudential justice, and corporate transformation: Becoming socially responsible in the internet age. Journal of Business Ethics, 90(4), 639648. https://doi.org/10.1007/978-94-007-0380-3 14

Marrone, M., \& Hazelton, J. (2019). The disruptive and transformative potential of new technologies for accounting, accountants and accountability. Meditari Accountancy Research. 27(5). 677-694. Retrieved from https:/ / econpapers.repec.org/scripts/redir.pf?u $=$ http $\% 3 \mathrm{~A} \% 2 \mathrm{~F} \% 2 \mathrm{Fwww} . e m e r a l d i n s i$ ght.com $\% 2 F 10.1108 \% 2 F M E D A R-06-2019-$ 0508\%3Futm campaign \%3DRePEc\%26WT.mc id \%3DRePEc; $\mathrm{h}=$ repec:eme:medap p:medar-06-2019-0508

McPhail, K., \& Walters, D. (2010). Accounting and Business Ethics: An Introduction. Accounting and Business Ethics: An Introduction, 85(1). 1-15. https://doi.org/10.2308/accr.2010.85.5.1817

Miller, K. W. (2010). Ethical analysis in the cloud. IT professional, 12(6), 7-9. https://doi.org/10.1109/mitp.2010.146

Mingers, J., \& Walsham, G. (2010). Toward ethical information systems: the contribution of discourse ethics. MIS quarterly, 34(4), 833-854. https://doi.org/10.2307/25750707

Murthy, U. S. (2016). Researching at the intersection of accounting and information technology: A call for action. Journal of Information Systems, 30(2), 159-167. https://doi.org/10.2308/isys-51413

Nakamoto, S. (2008). Bitcoin: A peer-to-peer electronic cash system, http://bitcoin.org/bitcoin.pdf. 
Ølnes, S., Ubacht, J., \& Janssen, M. (2017). Blockchain in government: Benefits and implications of distributed ledger technology for information sharing. Semantic Scholar, 22(1), 1-15. https://doi.org/10.1016/i.giq.2017.09.007

PricewaterhouseCoopers, P. (2016a). 2016 Global Industry 4.0 Survey Industry 4.0 : Building the digital enterprise [Press release]. Retrieved from https://doi.org/www.pwc.com/gx/en/industries/industrialmanufacturing/publications/assets/pwc-building-digital-enterprise.pdf.

PricewaterhouseCoopers, P. (2016b). Blockchain Solutions Portfolio [Press release]. Retrieved from https://www.pwc.com.au/publications/pdf/financial-servicesfintech-blockchain.pdf

Saunders, M. N. (2011). Research methods for business students, 5/e: Pearson Education India.

Schmitz, J., \& Leoni, G. (2019). Accounting and auditing at the time of blockchain technology: a research agenda. Australian Accounting Review, 29(2), 331-342. https://doi.org/10.1111/auar.12286

Setiawan, A., Lusanjaya, G., \& Kurnia, T. (2019). Rancangan Akuntansi 4.0 Dengan Pendekatan Systems Thinking. Journal of Accounting and Business Studies, 4(1), 1-15. https://journal.ithb.ac.id/index/index

Sheldon, M. D. (2018). Using Blockchain to aggregate and share misconduct issues across the accounting profession. Current Issues in Auditing, 12(2), 27-35. https://doi.org/10.2308/ciia-52184

Simoyama, F. D. O., Grigg, I., Bueno, R. L. P., \& Oliveira, L. C. D. (2017). Triple entry ledgers with blockchain for auditing. International Journal of Auditing Technology, 3(3), 163-183. https://doi.org/10.1504/ijaudit.2017.086741

Sinha, S. (2020). Blockchain Opportunities and challenges for accounting professionals. Journal of Corporate Accounting \& Finance, 31(2), 65-67. https://doi.org/10.1002/jcaf.22430

Stahl, B. C. (2012). Morality, ethics, and reflection: a categorization of normative IS research. Journal of the association for information systems, 13(8), 1-16. https://doi.org/10.17705/1jais.00304

Stuart, I., Stuart, B., \& Pedersen, L. J. (2014). Accounting ethics: Wiley Global Education.

Suddaby, R. (2006). From the editors: What grounded theory is not. Academy of Management 29(4). 150-170. https://doi.org/10.5465/amj.2006.22083020

Sumarna, A. D. (2020). Akuntan Dalam Industri 4.0: Studi Kasus Kantor Jasa Akuntan (KJA) di Wilayah Kepulauan Riau. KRISNA: Kumpulan Riset Akuntansi, 11(2), 100-109.

Tan, B. S., \& Low, K. Y. (2019). Blockchain as the database engine in the accounting system. Australian Accounting Review, 29(2), 312-318. https://doi.org/10.1111/auar.12278

Tang, Y., Xiong, J., Becerril-Arreola, R., \& Iyer, L. (2019a). Blockchain ethics research: a conceptual model. Paper presented at the Proceedings of the 2019 on Computers and People Research Conference.

Tang, Y., Xiong, J., Becerril-Arreola, R., \& Iyer, L. (2019b). Ethics of blockchain. Information Technology \& People. 33(2), 602-632. https://doi.org/10.1108/ITP-10-2018-0491

Vetter, A. (2018). Blockchain is already changing accounting. Accounting Today. Retrieved from https://www.accountingtoday.com/opinion/blockchain-is-already-changingaccounting\#

Weill, P., \& Woerner, S. L. (2015). Thriving in an increasingly digital ecosystem. MIT Sloan Management Review, 56(4), 27.

Yermack, D. (2017). Corporate governance and blockchains. Review of Finance, 21(1), 7-31. https://doi.org/10.3386/w21802 


\section{Haryanto \& Sudaryati}

The Ethical Perspective of Millennial Accountants in Responding ...

Zheng, Z., Xie, S., Dai, H.-N., Chen, X., \& Wang, H. (2018). Blockchain challenges and opportunities: A survey. International Journal of Web and Grid Services, 14(4), 352-375. https://doi.org/10.1504/ijwgs.2018.095647 